\title{
Production of essential oil-based composite nanofibers by emulsion electrospinning
}

\author{
Emülsiyon elektro lif çekim yöntemi ile uçucu yağ esaslı kompozit \\ nanoliflerin üretimi
}

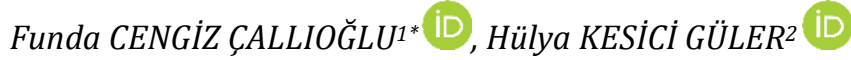 \\ 1,2Textile Engineering Department, Engineering Faculty, Suleyman Demirel University, Isparta, Turkey. \\ fundacengiz@sdu.edu.tr, kesicihulya@gmail.com
}

\begin{abstract}
This study aimed to produce polyvinylpyrrolidone (PVP)/gelatin (GEL)/lavender essential oil (LEO)-based nanofibers by means of oil-inwater emulsion electrospinning. Firstly, the polymer solution properties were measured, and then optimization of nanofiber production and characterization of the nanofibrous web were carried out. As gelatin was added to the PVP solution, viscosity was found to increase while surface tension and conductivity decreased. PVP/GEL (50/50) was determined to be the optimum sample in terms of nanoweb quality, fiber diameter, diameter uniformity, and gelatin content. Nanofiber production proceeded with PVP/GEL (50/50) and various concentrations of LEO. FT-IR results confirmed that LEO, PVP, and gelatin were incorporated in the chemical structure of the nanofibers. Generally, ultra-fine and uniform nanofibers were obtained, except when using pure PVP or PVP/GEL (50/50) including 8 wt \% LEO. The finest fibers were obtained from PVP/GEL (100/0) (183 nm), and the most uniform fibers were obtained from PVP/GEL (50/50) (fiber diameter uniformity coefficient of 1.04). All nanofiber samples displayed unimodal distribution curves of histograms. While the addition of gelatin affected solution properties and average fiber diameter, the addition of LEO did not affect fiber properties.
\end{abstract}

Keywords: Polyvinylpyrrolidone, gelatin, lavender essential oil emulsion electrospinning, nanofiber

\section{Introduction}

Emulsion electrospinning is a new, green approach for the production of nanofibers. It enables the generation of nanofiber from immiscible liquids such as essential oils and hydrophobic drugs and proteins; indeed, it is the most suitable method for combining nanofibers with essential oils [1]-[4]. Normally, it is very difficult but not impossible to produce nanofibers from an aqueous polymer solution and an essential oil. Emulsion electrospinning enables the preparation of stable and homogenous emulsion solutions, making it far easier to produce nanofibers. Another advantage of this method is that it does not require extra apparatus over the conventional electrospinning system. Furthermore, emulsion electrospinning represents a big step towards green electrospinning. The main aim of green electrospinning is the use of green chemicals, which are very important in terms of environmental impact and end-product properties [5]-[6]. In recent years, nanofibers have become very attractive for medical and cosmetic applications, for which a green
Öz

Bu çalıșmada, su içinde yağ emülsiyon elektro lif çekimi ile polivinilpirolidon (PVP)/jelatin (GEL)/lavanta uçucu yağ (LEO) esash nanolif üretilmesi amaçlanmıştır. Öncelikle; polimer çözelti özelliklerinin ölçümü ve daha sonra nanolif üretim optimizasyonu ve nanolifli ă̆ yapının karakterizasyonu gerçekleștirilmiştir. PVP çözeltisine jelatin ilavesi ile viskozite artar iken, iletkenlik ve yüzey gerilimi azalmaktadır. Nano ağ kalitesi, lif çapı, çap üniformitesi ve jelatin içeriği bakımından PVP/GEL (50/50) optimum numune olarak belirlenmiștir. Ceșitli konsantrasyonlarda LEO içeren PVP/GEL (50/50)'den nanolif üretimine devam edilmiştir. FT-IR sonuçları, nanoliflerin kimyasal yapısında LEO, PVP ve jelatin varlığın doğrulamıştır. Saf PVP ve \%8 LEO içeren PVP/GEL (50/50) hariç, genellikle oldukça ince ve üniform nanolifler elde edilmistir. En ince lifler PVP/GEL (100/0) (183 nm) çözeltisinden ve en üniform lifler PVP/GEL (50/50) (1.04 lif çapı üniformite katsayısı) çözeltisinden elde edilmiștir. Tüm nanolif numunelerinin histogramında tek tepeli dağılım eğrileri elde edilmiștir. Jelatin ilavesi, çözelti özelliklerini ve ortalama lif çapını istatistiksel olarak etkilemiștir fakat LEO ilavesi lif özelliklerini etkilememiștir.

Anahtar kelimeler: Polivinilpirolidon, jelatin, lavanta uçucu yağı, emülsiyon elektro lif çekimi, nanolif.

electrospinning approach has vital importance. For these reasons, this study explored the production of nanofibrous composite material including PVP/gelatin/lavender essential oil (LEO) by oil-in-water emulsion electrospinning.

PVP and gelatin were used as the polymers in this study due to their particular properties. Namely, PVP is a biocompatible, non-toxic, water-soluble, hydrophilic, and synthetic polymer, whose use in nanofibrous surfaces for biomedical applications has been explored in the literature [7]-[11]. Prior work has carried out the electrospinning of PVP mixtures including; poly(ethylene oxide)/PVP [7], poly( $\varepsilon$-caprolactone)/PVP [8], zein/PVP [12], dextran/PVP [13], poly(vinylidene fluoride)/PVP [14], and ethyl cellulose/PVP [15]. Meanwhile, gelatin is a natural, protein-based polymer that features the intrinsic properties of nonimmunogenicity, biodegradability, biocompatibility, good cell adhesion, and mucoadhesion; these properties are important for medical and cosmetic applications [16]-[18]. While there are a lot of prior studies about gelatinbased nanofibrous surfaces, these combined gelatin with organic, toxic and harmful solvents such as 
2,2,2-trifluoroethanol (TFE) [19]-[20], trifluoroacetic acid (TFA) [21],[16], and 1,1,1,3,3,3-hexafluoro-2-propanol (HFP) [22]-[25]. Others have explored electrospinning gelatin nanofibers from mixtures such as chitosan/gelatin [16],[26], poly( $\varepsilon$-caprolactone)/gelatin [23]-[24], polyaniline/gelatin [25], poly(lactic-co-glycolic acid)/gelatin [20],[27]-[28], and silk fibroin/gelatin [29]. Our study differs from prior work by using a green solvent (acetic acid) to prepare the gelatin solutions. Furthermore, to our knowledge, there has been no study of PVP/gelatin-blended and LEO-added nanofibers prepared by emulsion electrospinning. This study is distinctive in this aspect from other studies.

Essential oils are odorant oils that can be produced from different parts of medicinal and aromatic plants [30]-[32]. The essential oil from lavender (Lavandula hybrida L.), which was used as an additive in this study, has antiseptic, antibacterial, sedative, tranquillizer, antioxidant, and relaxing properties; and therefore can be used in the application areas of perfumery, pharmacology, medicine, and especially aromatherapy [33][35]. Also, LEO is a commercial product of Isparta province, Turkey, and it is thought that with this study, this commercial product can enter into new application areas such as nanoscale cosmetics and biomedical materials.

Limited studies exist concerning nanofibers produced with essential oils or the major constituents of essential oils. [36] Kayaci et al. (2013) investigated the thermal stability and release profile of eugenol in polyvinyl alcohol (PVA) nanofibers containing eugenol (EG)/cyclodextrin (CD) inclusion complexes. Three type of cyclodextrin ( $\alpha$-CD, $\beta$-CD, and $\gamma$-CD) were used in the nanofiber structures. They found that the $\mathrm{PVA} / \mathrm{EG} / \gamma$-CD inclusion complex demonstrated higher thermal stability and slower release of eugenol, and suggested that this nanofibrous surface can be used in the food industry to leverage properties of eugenol such as its antibacterial, antifungal, and antioxidant efficacies. [4] Kesici Güler et al. (2018) studied the emulsion electrospinning of oil-in-water emulsions containing PVP/cinnamon essential oil solutions. They successfully and homogeneously incorporated cinnamon essential oil in the nanofiber structure and investigated the antibacterial activity of the nanofibers; the authors suggested that these nanofibers with cinnamon essential oil could be used for biomedical materials. [37] Kim et al. (2016) produced PVA nanofibers loaded with Juniperus chinensis extracts for enhanced antibacterial activity. They obtained very smooth and regular nanofibers, and found the composite nanofibers to have excellent antibacterial activity against both Gram-positive and Gram-negative bacteria. [38] Mori et al. (2015) investigated the production of nanofibers from polylactic acid (PLA) and candeia (Eremanthus erythropappus), and investigated the fiber morphology and structure. They determined that the nanofibers had homogeneous structures incorporating the candeia essential oil, and that increased proportions of candeia essential oil increased the nanofiber diameter and decreased the glass transition and melting temperatures. However, it could not be found any literature on emulsion electrospun nanofibers incorporating LEO. To explore the properties and potential of such nanofibers, PVP and gelatin polymers and the additive LEO were chosen as raw materials for this study of a nanofibrous composite material that might be useful for cosmetic and medical applications.

\section{Materials and methods}

\section{$2.1 \quad$ Materials}

PVP (Mw $360.000 \mathrm{~g} / \mathrm{mol}$ ) and gelatin (type A) were used as polymers, a surfactant (PEG-40 hydrogenated castor oil) was used as an emulsifier and lavender essential oil (Lavandula hybrida L.) was used as an additive for the produced nanofibrous composite material. Green solvents were selected from solvent selection guides [39], and consisted of distilled water (DW) and acetic acid (AA). PVP, gelatin, and acetic acid were purchased from Sigma-Aldrich; the surfactant was supplied by Ersa Chemistry, İzmir, Turkey; and the lavender essential oil was acquired from Botalife, Isparta, Turkey. All chemicals were analytical grade and used without further purification. Polymer solution optimization consisted of two stages. In the first stage, solutions were prepared with different proportions of PVP (12 wt \%) in distilled water and gelatin (6 wt \%) in acetic acid (Table 1 ).

Table 1. PVP/DW and GEL/AA polymer solutions and mixture ratios.

\begin{tabular}{cccc}
\hline $\begin{array}{c}\text { Sample } \\
\text { codes }\end{array}$ & $\begin{array}{c}\text { PVP/DW } \\
\text { (wt \%) }\end{array}$ & $\begin{array}{c}\text { GEL/AA } \\
\text { (wt \%) }\end{array}$ & $\begin{array}{c}\text { Mixture ratio } \\
\text { (PVP/GEL) } \\
\text { (wt \%) }\end{array}$ \\
\hline PVP0 & 12 & 6 & $0 / 100$ \\
PVP25 & 12 & 6 & $25 / 75$ \\
PVP50 & 12 & 6 & $50 / 50$ \\
PVP75 & 12 & 6 & $75 / 25$ \\
PVP100 & 12 & 6 & $100 / 0$ \\
\hline
\end{tabular}

For the second stage of this study, PVP50 was chosen as the optimum nanofibrous surface in terms of fiber morphology, fiber diameter, and gelatin content of the nanofibrous composite. Next, LEO was added at various concentrations $(0,2,4,6$ and 8 wt \%) (Table 2). Also, the surfactant concentration was set at $3 \mathrm{wt} \%$, as determined from our preliminary studies. All polymer solutions were prepared under the same conditions such as; stirring time, stirring rate and temperature (Figure 1).

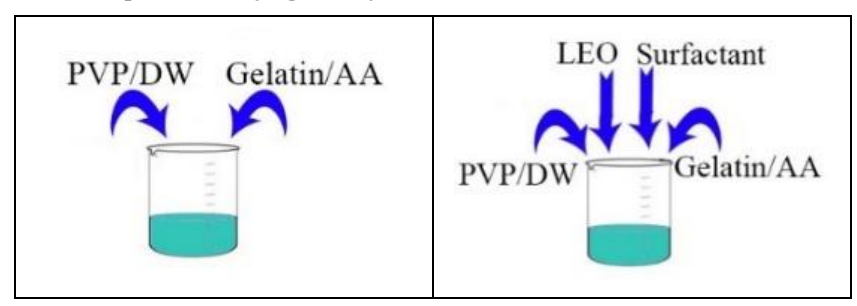

(a)

(b)

Figure 1. Schematic representation of solution preparation. (a): First stage, (b): Second stage

\subsection{Method}

Solution properties such as; conductivity, viscosity (under a shear rate of $5 \mathrm{~s}^{-1}$ ) and surface tension (by the Wilhelmy plate method) were determined. Next, nanofiber production was carried out with the electrospinning method. Optimum process parameters are given in Table 3 , and all nanofibers were produced for the same duration ( $30 \mathrm{~min}$.). Figure 2 shows a representation of the emulsion electrospinning method used in this study. 
Table 2. PVP/GEL (50/50) polymer solutions with various concentrations of LEO.

\begin{tabular}{|c|c|c|c|c|c|}
\hline Sample codes & $\begin{array}{c}\text { PVP/DW } \\
\text { (wt \%) }\end{array}$ & $\begin{array}{l}\text { GEL/AA } \\
\text { (wt \%) }\end{array}$ & $\begin{array}{c}\text { Mixture ratio } \\
\text { (PVP/GEL) (wt \%) }\end{array}$ & $\begin{array}{c}\text { Surfactant } \\
(\%)\end{array}$ & $\begin{array}{c}\text { LEO } \\
\text { (wt \%) }\end{array}$ \\
\hline PVP50 & 12 & 6 & $50 / 50$ & 3 & 0 \\
\hline PVP50-L2 & 12 & 6 & $50 / 50$ & 3 & 2 \\
\hline PVP50-L4 & 12 & 6 & $50 / 50$ & 3 & 4 \\
\hline PVP50-L6 & 12 & 6 & $50 / 50$ & 3 & 6 \\
\hline PVP50-L8 & 12 & 6 & $50 / 50$ & 3 & 8 \\
\hline \multicolumn{6}{|c|}{ Table 3. Optimum parameters for electrospinning process. } \\
\hline \multicolumn{3}{|c|}{ Voltage $(\mathrm{kV})$} & \multicolumn{3}{|c|}{22.4} \\
\hline \multicolumn{3}{|c|}{ Distance between electrodes $(\mathrm{cm})$} & \multicolumn{3}{|c|}{16.5} \\
\hline \multicolumn{3}{|c|}{ Feed rate $(\mathrm{mL} / \mathrm{h})$} & \multicolumn{3}{|c|}{0.8} \\
\hline \multicolumn{3}{|c|}{ Humidity (\%) } & \multicolumn{3}{|c|}{$35 \pm 1$} \\
\hline \multicolumn{3}{|c|}{ Temperature $\left({ }^{\circ} \mathrm{C}\right)$} & \multicolumn{3}{|c|}{$23 \pm 1$} \\
\hline \multicolumn{3}{|c|}{ Needle Diameter (mm) } & \multicolumn{3}{|c|}{0.8} \\
\hline
\end{tabular}

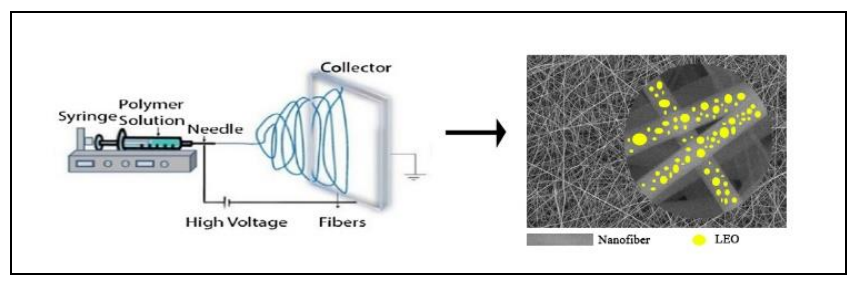

Figure 2. Schematic representation of emulsion electrospinning.

Average fiber diameter and nanoweb quality were determined via scanning electron microscopy (SEM) using a FEI Quanta 250 FEG model. Fiber diameters were measured using ImageJ software, and the fiber diameter uniformity coefficient (FDUC) was calculated using formulas (1) and (2) given below [40].

$$
\begin{aligned}
A_{n} & =\frac{\sum n_{i} d_{i}}{\sum n_{i}} \text { (number average) } \\
A_{w} & =\frac{\sum n_{i} d_{i}^{2}}{\sum n_{i} d_{i}} \text { (weight average) }
\end{aligned}
$$

$d_{i}$ : Fiber diameter. $n_{i}$ : Fiber number.

Composite nanofibrous surfaces were analysed by Fourier transform-infrared spectroscopy (FT-IR) to determine their chemical structures. For all samples, IR spectra were analyzed over the $400-4000 \mathrm{~cm}^{-1}$ range with a resolution of $4 \mathrm{~cm}^{-1}$.

Lastly, nanofiber diameter histograms were overlaid with a normal distribution curve, and nanofiber diameters were analysed by one-way ANOVA with statistical significance set at $p<0.05$.

\section{Results and discussion}

\subsection{Solution Properties}

Figure 3 shows the obtained conductivity, surface tension, and viscosity values for PVP/GEL solutions. As illustrated in Figure $3(\mathrm{a})$, viscosity decreases and conductivity increases with decreasing gelatin concentration. It is possible to say that the addition of gelatin influences viscosity and conductivity significantly. Viscosity and conductivity measurements could not be made for sample PVP0 (PVP/GEL [0/100]) because of the ambient laboratory temperature was below the solution's gelation point. Overall, the viscosity results are compatible with the literature; [41] Song et al. (2017) determined that there is a direct correlation between solution viscosity and gelatin concentration. However, [42] Okutan et al. (2014) reported that solution conductivity increased with gelatin concentration, different from our results. This inconsistency may be due to their usage of a different type of gelatin (type B), solvent (ethanol), and polymer mixture. Figure 3(b) shows that surface tension values increase with less gelatin content. Also, it is possible to say that there is a strong relationship between spinnability, fiber morphology, and surface tension. During the experiment, spinnability was observed to decrease from sample PVP25 to sample PVP100. Therefore, gelatin addition improves spinnability excitingly.

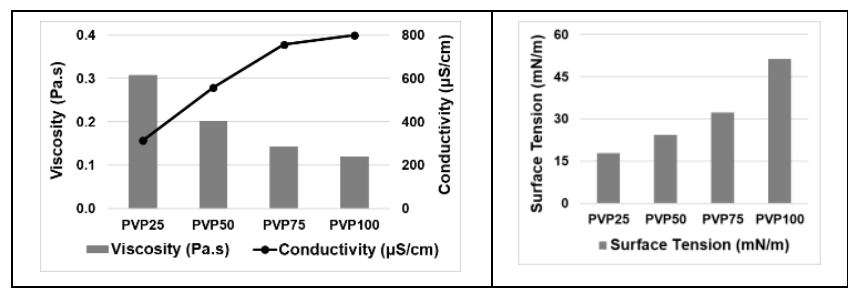

(a)

(b)

Figure 3. Properties of PVP/GEL solutions. (a): Conductivity and viscosity results, (b): Surface tension results.

The conductivity, surface tension, and viscosity of PVP/GEL (50/50) (sample PVP50) solutions also including LEO are given in Figure 4. As is clearly seen in Figure 4(a), conductivity decreased with increasing LEO concentration. This result is expected because the conductivity value of pure LEO is $0.13 \mu \mathrm{S} / \mathrm{cm}$, which is quite low. In addition, increasing LEO concentration caused viscosity to increase and surface tension to decrease.

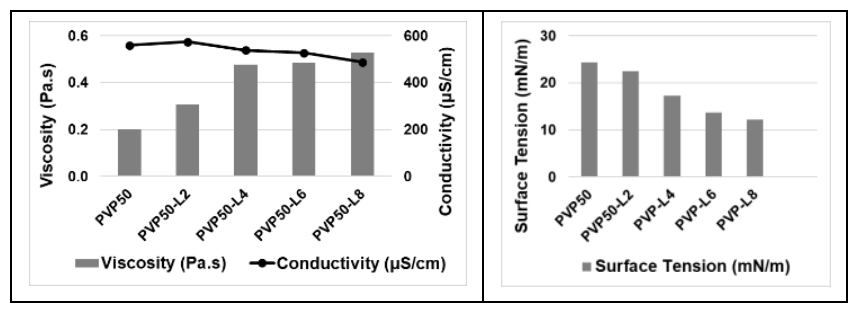

(a)

(b)

Figure 4. Properties of PVP/GEL/LEO solutions.

(a): Conductivity and viscosity, (b): Surface tension results. 


\subsection{Fiber morphology}

SEM images and fiber diameter histograms of various mixtures of PVP/GEL nanofibers are given in Figure 5. Mostly, the nanofibers produced were quite fine and had a homogeneous distribution; the exception is sample PVP100 (PVP/DW), which had some beads in its fiber structure. In addition, it was not possible to spin nanofibers from sample PVP0, because of solution gelation. All samples displayed unimodal histogram curves (PVP25, PVP50, PVP75 and PVP100).

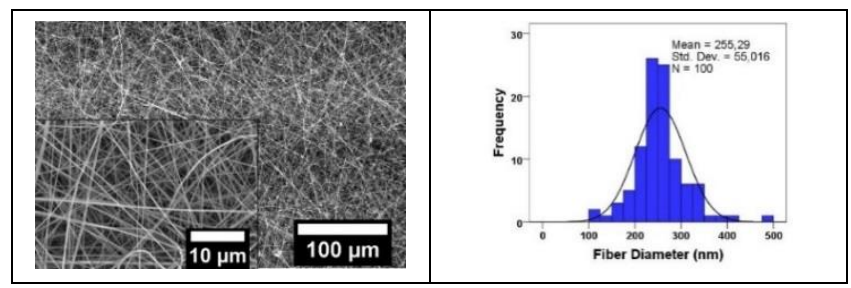

PVP25

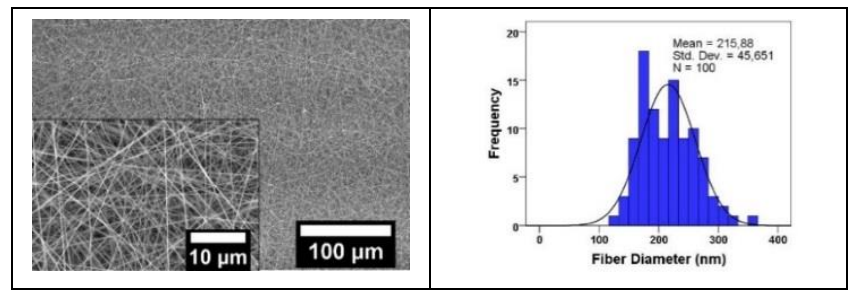

PVP50

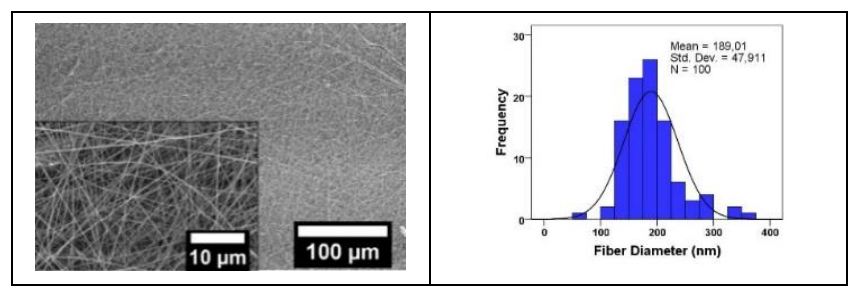

PVP75

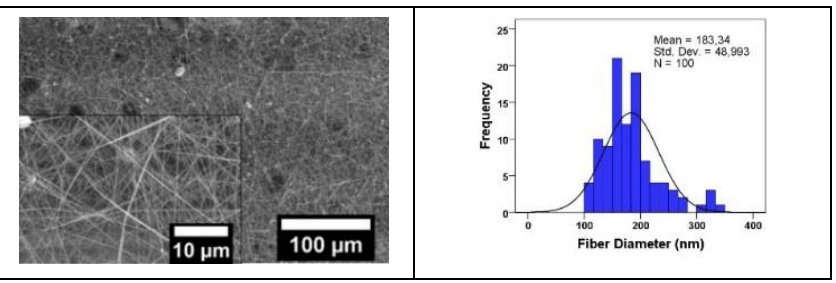

PVP100

Figure 5. SEM images (1.000x-10.000x) and fiber diameter histograms of nanofibers for all PVP/GEL ratios.

From analyses of fiber diameter and diameter uniformity coefficient (Figure 6), it was determined that gelatin addition decreases average fiber fineness. This finding is compatible with the viscosity results (Figure 3(a)) and existing literature. It is possible to say that the addition of gelatin had a statistically significant effect on the average fiber diameter of PVP nanofibers. The finest fibers $(183 \mathrm{~nm})$ were obtained from sample PVP100, (PVP/DW) but it also had the worst fiber morphology, with beads observed. The most uniform nanofibers (at FDUC $=1.04$ ) were obtained from sample PVP50 (PVP/GEL 50/50). Sample PVP50 was chosen as the most suitable sample for the second stage of the study in terms of average fiber diameter, fiber diameter uniformity coefficient, fiber morphology, and quantity of gelatin content.

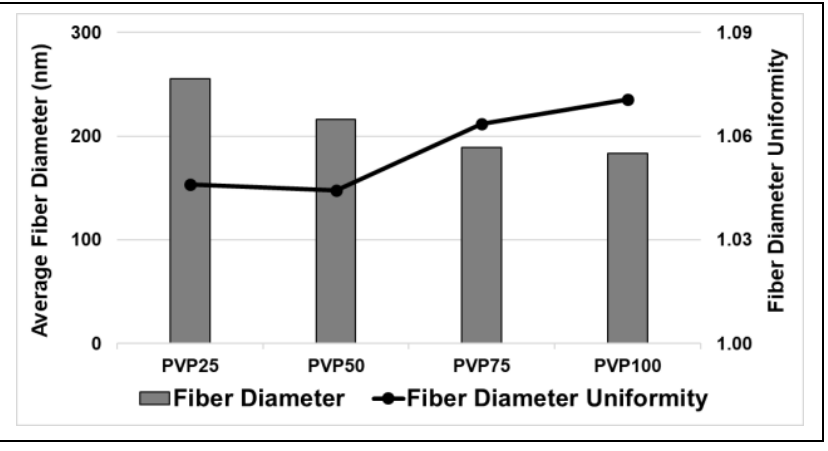

Figure 6. Average fiber diameters and FDUC values of nanofibers produced from PVP/GEL solutions.

Figure 7 shows representative SEM pictures and fiber diameter histograms of nanofibers produced from PVP/GEL (50/50) with various concentrations of LEO added.
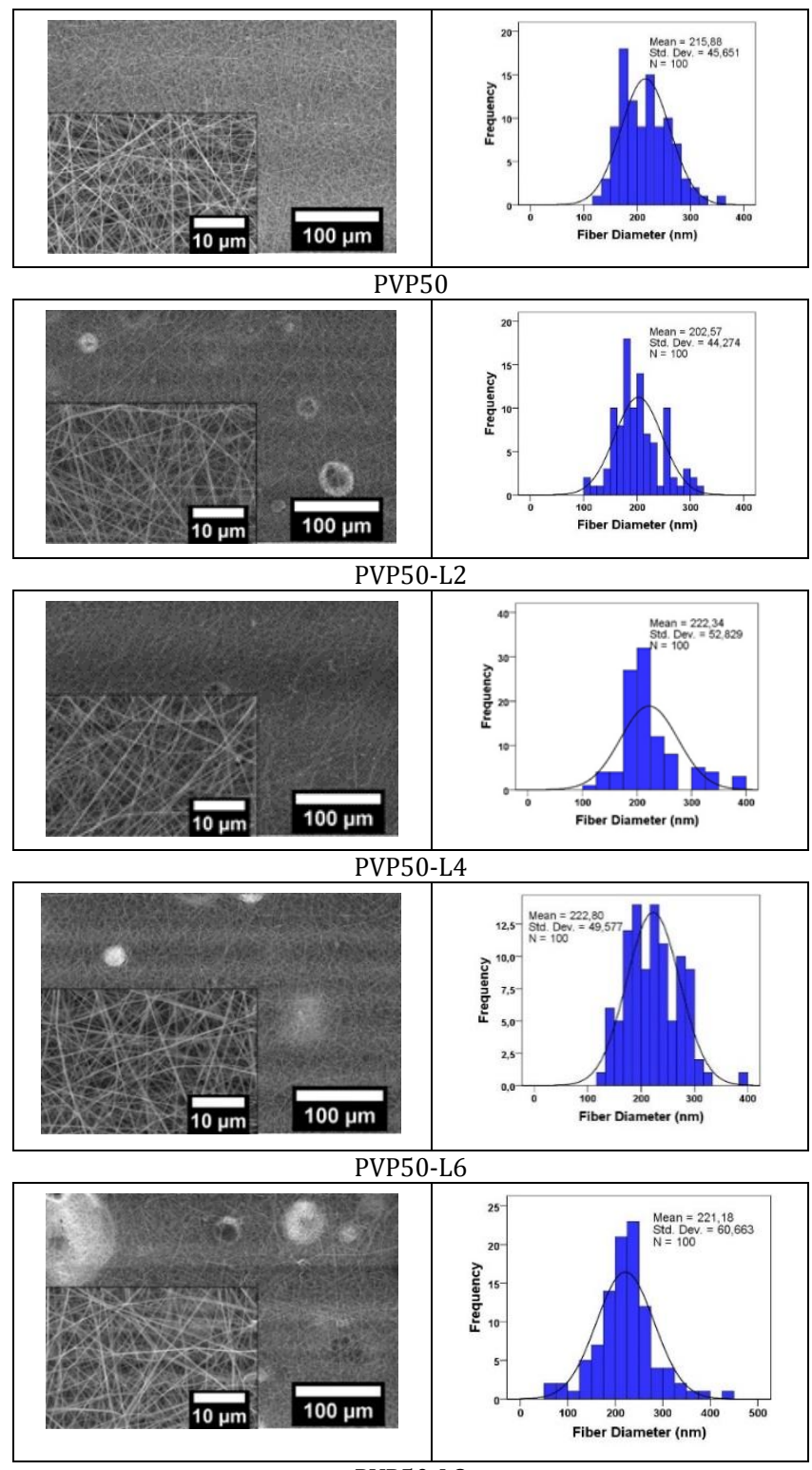

PVP50-L8

Figure 7. SEM images $(1000 \mathrm{x}-10000 \mathrm{x})$ and fiber diameter histograms of PVP/GEL nanofibers produced with various LEO concentrations. 
The results showed that LEO concentration did not significantly affect nanofiber diameter and FDUC (Figure 8). Some beads were present in sample PVP50-L8, and it is thought that morphological deformation starts at this concentration; therefore, it is possible to say that 8 wt \% LEO is not suitable for use with PVP/GEL (50/50). Generally, quite fine and uniform nanofibers were produced in the second stage of this study. The finest fibers $(202.57 \mathrm{~nm})$ were obtained from sample PVP50$\mathrm{L} 2$, and the most uniform fibers (FDUC=1.04) were obtained from sample PVP50-L6. All samples again displayed unimodal histogram curves (Figure 7).

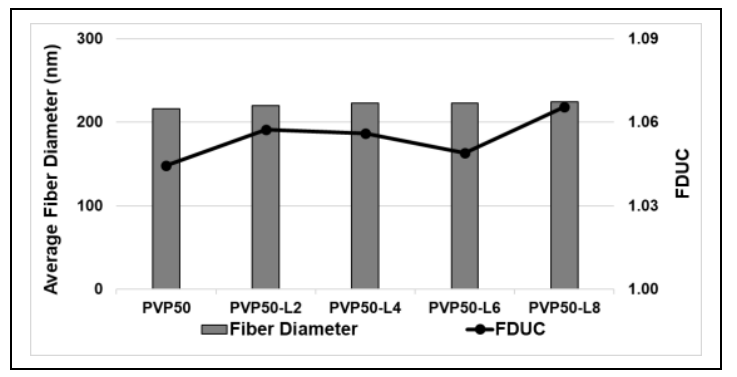

Figure 8. Average fiber diameters and FDUC values for nanofibers from PVP/GEL/LEO solutions.

During the experimental studies and analyses, it became apparent that solution conductivity has an important effect on spinnability and the fiber morphology. A graph of the relationship between solution conductivity and average fiber diameter for PVP/GEL solutions is given in Figure 9.

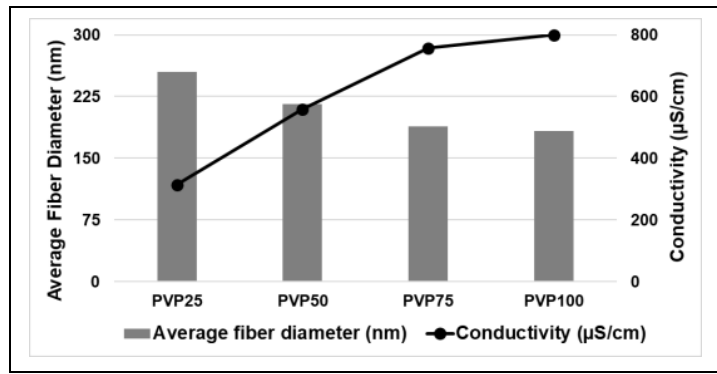

Figure 9. Relationship between solution conductivity and average fiber diameter for PVP/GEL solutions.

In short, there is an inverse correlation between solution conductivity and average fiber diameter. Therefore, finer nanofibers, which are important for nanoweb quality, can be produced with high-conductivity polymer solutions. These results are compatible with reports in the literature [43]-[44].

In the second stage of this study, neither solution conductivity nor average fiber diameter were changed significantly by the addition of LEO (Figure 10).

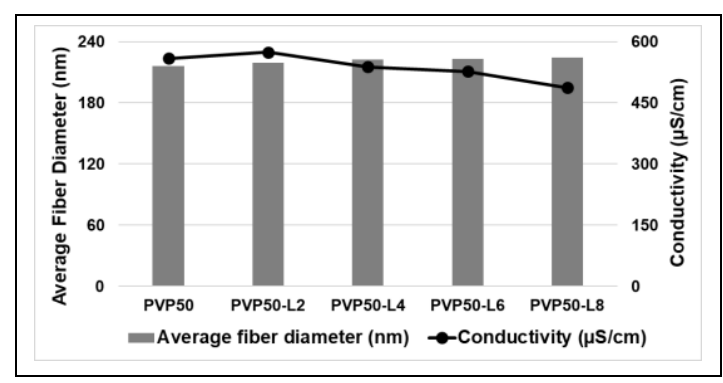

Figure 10. Relationship between solution conductivity and average fiber diameter for PVP/GEL/LEO solutions.
It is also possible to say there is a direct relationship between solution conductivity and FDUC (Figure 11); that is, as the gelatin content decreases, conductivity increases and fiber diameter uniformity decreases, which results in greater fineness of fibers. As was mentioned in relation to Figure 9, average fiber diameter decreases with increasing solution conductivity, and this result is expected from literature [43][44].

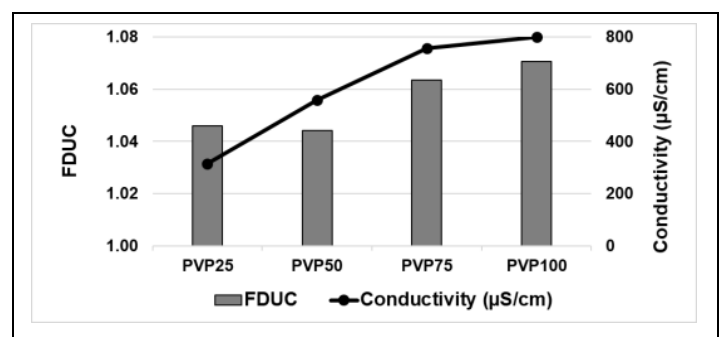

Figure 11. Relationship between solution conductivity and FDUC for PVP/GEL solutions

Analysis showed that FDUC is affected slightly by LEO addition, and that solution conductivity decreases with increasing LEO concentration (Figure 12).

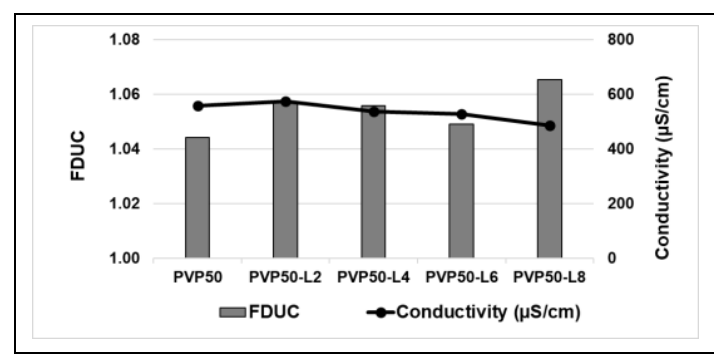

Figure 12. Relationship between solution conductivity and FDUC for PVP/GEL/LEO solutions.

All results concerning solution and fiber properties of PVP/GEL and PVP/GEL/LEO samples are given in Table 4.

Lastly, FT-IR analyses demonstrated that LEO, PVP, and GEL were present in the chemical structures of nanofibrous materials (Figure 13).

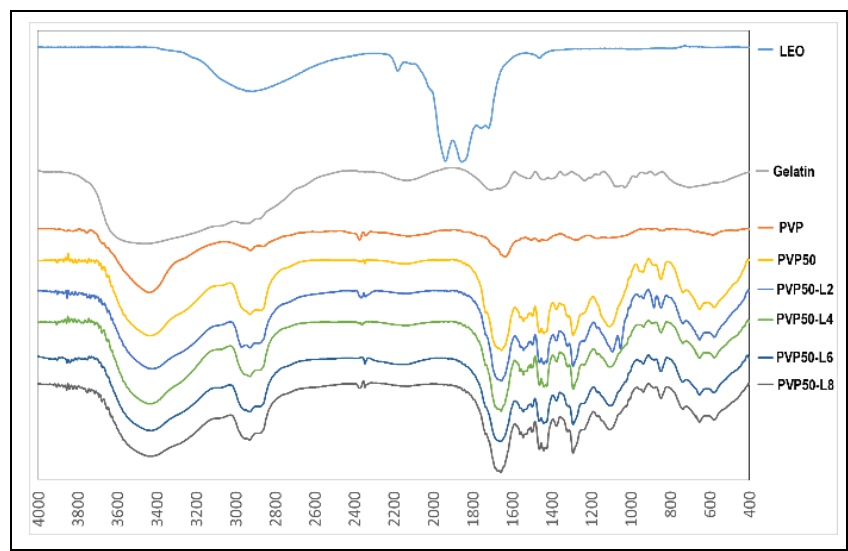

Figure 13. FT-IR spectra of PVP/gelatin (50/50) nanofiber samples which includes LEO.

In the PVP spectrum, an $\mathrm{OH}$ stretching peak was evident at $3434 \mathrm{~cm}^{-1}$. The same peak appeared at $3431 \mathrm{~cm}^{-1}$ in sample PVP50, $3419 \mathrm{~cm}^{-1}$ in PVP50-L2, $3433 \mathrm{~cm}^{-1}$ in PVP50-L4, 3424 $\mathrm{cm}^{-1}$ in PVP50-L6, and $3424 \mathrm{~cm}^{-1}$ in PVP50-L8. Another strong peak showed at $2924 \mathrm{~cm}^{-1}$ in the spectrum of the PVP polymer. 
Table 4. Solution and fiber properties for all PVP/GEL and PVP/GEL/LEO samples.

\begin{tabular}{|c|c|c|c|c|c|c|c|c|}
\hline $\begin{array}{l}\text { Sample } \\
\text { Code }\end{array}$ & $\begin{array}{l}\text { Conductivity } \\
(\mu \mathrm{S} / \mathrm{cm})\end{array}$ & $\begin{array}{l}\text { Surface } \\
\text { Tension } \\
(\mathrm{mN} / \mathrm{m})\end{array}$ & $\begin{array}{l}\text { Viscosity } \\
\text { (Pa.s) }\end{array}$ & $\begin{array}{c}\text { Weight } \\
\text { Average } \\
\text { Diameter } \\
\left(\mathrm{A}_{\mathrm{w}}\right)(\mathrm{nm})\end{array}$ & $\begin{array}{l}\text { Number } \\
\text { Average } \\
\text { Diameter } \\
\left(\mathrm{A}_{\mathrm{n}}\right)(\mathrm{nm})\end{array}$ & $\begin{array}{c}\text { FDUC } \\
\left(A_{w} / A_{n}\right)\end{array}$ & $\begin{array}{l}\text { Fiber Diameter } \\
\text { Range (nm) }\end{array}$ & $\begin{array}{l}\text { Nanoweb } \\
\text { Quality }\end{array}$ \\
\hline PVP0 & - & - & - & - & - & - & - & Not spinnable \\
\hline PVP25 & 314 & 17.80 & 308 & 267 & 255 & 1.046 & $103-476$ & Smooth \\
\hline PVP50 & 559 & 24.35 & 202 & 225 & 216 & 1.044 & $127-310$ & Smoothest \\
\hline PVP75 & 757 & 32.37 & 143 & 201 & 189 & 1.064 & $118-337$ & Smoothest \\
\hline PVP100 & 799 & 51.28 & 120 & 196 & 183 & 1.071 & $108-317$ & Beads \\
\hline PVP50-L2 & 574 & 22.47 & 306 & 232 & 219 & 1.057 & $152-365$ & Smooth \\
\hline PVP50-L4 & 538 & 17.24 & 477 & 235 & 222 & 1.056 & $101-398$ & Smoothest \\
\hline PVP50-L6 & 527 & 13.61 & 485 & 234 & 223 & 1.049 & $128-301$ & Smooth \\
\hline PVP50-L8 & 487 & 12.21 & 530 & 239 & 224 & 1.065 & $53-390$ & Sticky \\
\hline
\end{tabular}

This peak appeared at $2926 \mathrm{~cm}^{-1}, 2925 \mathrm{~cm}^{-1}, 2926 \mathrm{~cm}^{-1}, 2927$ $\mathrm{cm}^{-1}$, and $2927 \mathrm{~cm}^{-1}$ in the spectra of PVP50, PVP50-L2, PVP50L4, PVP50-L6, and PVP50-L8, respectively. The C=0 peak of the PVP spectrum is another characteristic peak; it appeared at $1635 \mathrm{~cm}^{-1}$ in the PVP spectrum and at $1653 \mathrm{~cm}^{-1}, 1654 \mathrm{~cm}^{-1}$, and $1655 \mathrm{~cm}^{-1}$ in all sample spectra. The spectra of gelatin polymers and nanofibrous materials showed different absorption bands relating to amide I, amide II, and amide III. These peaks appeared around $1705 \mathrm{~cm}^{-1}, 1516 \mathrm{~cm}^{-1}$, and $1232 \mathrm{~cm}^{-1}$, respectively. In the gelatin spectrum, there was a $\mathrm{CH}_{2}$ stretching peak at $2936 \mathrm{~cm}^{-1}$ that also appeared at $2926 \mathrm{~cm}^{-1}, 2925 \mathrm{~cm}^{-1}$, $2926 \mathrm{~cm}^{-1}, 2927 \mathrm{~cm}^{-1}$, and $2927 \mathrm{~cm}^{-1}$ in the spectra of PVP50, PVP50-L2, PVP50-L4, PVP50-L6, and PVP50-L8. Finally, a feeble peak at $3088 \mathrm{~cm}^{-1}$ was observed in the LEO spectrum. This peak occurred in all sample spectra. The fingerprint peaks indicated in the LEO spectrum occurred between 1800 and 600 $\mathrm{cm}^{-1}$, and were observed in all sample spectra.

\section{Conclusions}

Firstly, this study produced composite nanofibers using various mixture ratios of PVP/GEL polymers $(0 / 100,25 / 75,50 / 50$, $75 / 25$ and $100 / 0)$. After the determination of the optimum mixture, PVP/GEL (50/50), the addition of various concentrations of LEO was applied $(0,2,4,6$, and $8 \mathrm{wt} \%)$. The results demonstrated that gelatin concentration has important effects on the solution conductivity, surface tension, viscosity, and fiber morphology. It was determined that as the gelatin concentration increases, solution viscosity also increases while conductivity and surface tension decrease. Another result of added gelatin was enhanced fiber morphology (without beads) and increased average fiber diameter. In contrast, LEO concentration did not have any significant effect on the average fiber diameter, but did impact solution properties (conductivity, surface tension, and viscosity). Solution viscosity increased with LEO concentration while conductivity decreased, but surface tension did not change. Generally, very fine and uniform nanofibers were produced from PVP/GEL/LEO solutions. Lastly, FT-IR results confirmed that LEO, PVP, and gelatin were present in the structures of all nanofibers samples. These aromatic composite materials have potential use in cosmetic and biomedical applications and the advantages of incorporating biocompatible polymers, green solvents, a non-toxic surfactant, and a natural additive.

\section{References}

[1] Agarwal S, Greine A. "On the way to clean and safe electrospinning-green electrospinning: emulsion and suspension electrospinning". Polymers for Advanced Technologies, 22, 372-378, 2011.

[2] Hu J, Wei J, Liu W, Chen Y. "Preparation and characterization of electrospun PLGA/gelatin nanofibers as a drug delivery system by emulsion electrospinning". Journal of Biomaterials Science, Polymer Edition, 24(8), 972-985, 2013.

[3] Briggs T, Arinzeh TL. "Examining the formulation of emulsion electrospinning for improving the release of bioactive proteins from electrospun fibers". Journal of Biomedical Materials Research Part A, 102, 674-684, 2014.

[4] Kesici Güler H, Cengiz Çallığlu F, Sesli Çetin E. "Antibacterial PVP/cinnamon essential oil nanofibers by emulsion electrospinning". The Journal of the Textile Institute, 110(2), 302-310, 2019.

[5] Padil VVT, Wacławek S, Černík M. “Green Synthesis: Nanoparticles and Nanofibres Based on Tree Gums for Environmental Applications". Ecological Chemistry and Engineering S, 23(4), 533-557, 2016.

[6] Castilla-Casadiego DA, ''Green' electrospinning of a collagen/hydroxyapatite composite nanofibrous scaffold". MRS Communications, 6(4), 402-407, 2016.

[7] Burke L, Mortimer CJ, Curtis DJ, Lewis AR, Williams R, Hawkins K, Wright CJ. "In-situ synthesis of magnetic ironoxide nanoparticle-nanofibre composites using electrospinning". Materials Science \& Engineering. C, Materials for Biological Applications, 70(1), 512-519, 2017.

[8] Han D, Sasaki M, Yoshino H, Kofuji S, Sasaki AT, Steckl AJ. "In-vitro evaluation of MPA-loaded electrospun coaxial fiber membranes for local treatment of glioblastoma tumor cells". Journal of Drug Delivery Science and Technology, 40, 45-50, 2017.

[9] Gharib R, Najjar A, Auezova L, Charcosset C, Greige-Gerges $\mathrm{H}$, "Interaction of Selected Phenylpropenes with Dipalmitoylphosphatidylcholine Membrane and Their Relevance to Antibacterial Activity". The Journal of Membrane Biology, 250(3), 259-271, 2017. 
[10] Wang L, Chang MW, Ahmad Z, Zheng H, Li JS. "Mass and controlled fabrication of aligned PVP fibers for matrix type antibiotic drug delivery systems". Chemical Engineering Journal, 307, 661-669, 2017.

[11] Yu DG, Wang X, Li XY, Chian W, Li Y, Liao YZ. “Electrospun biphasic drug release polyvinylpyrrolidone/ethyl cellulose core/sheath nanofibers". Acta Biomaterialia, 9(3), 5665-5672, 2013.

[12] Jiang YN, Mo HY, Yu DG. "Electrospun drug-loaded core-sheath PVP/zein nanofibers for biphasic drug release". International Journal of Pharmaceutics, 438(1-2), 232-239, 2012.

[13] Maslakci NN, Ulusoy S, Uygun E, Çevikbaş H, Oksuz L, Can HK, Oksuz AU. "Ibuprofen and acetylsalicylic acid loaded electrospun PVP-dextran nanofiber mats for biomedical applications". Polymer Bulletin, 74(8), 3283-3299, 2017.

[14] Rajasekhar T, Babu PV, Gopinath J, Sainath AVS, Reddy AVR. "Amphiphilic ABA-type triblock copolymers for the development of high-performance poly (vinylidene fluoride)/poly (vinyl pyrrolidone) blend ultrafiltration membranes for oil separation". Journal of Applied Polymer Science, 134(36), 1-13, 2017.

[15] Yu DG, Wang X, Li XY, Chian W, Li Y, Liao YZ. “Electrospun biphasic drug release polyvinylpyrrolidone/ethyl cellulose core/sheath nanofibers". Acta Biomaterialia, 9(3), 5665-5672, 2013.

[16] Dhandayuthapani B, Krishnan UM, Sethuraman S. "Fabrication and characterization of chitosan-gelatin blend nanofibers for skin tissue engineering". Journal of Biomedical Materials Research. Part B, Applied Biomaterials, 94(1), 264-272, 2010.

[17] Huang ZM, Zhang YZ, Ramakrishna S, Lim CT. "Electrospinning and mechanical characterization of gelatin nanofibers". Polymer, 45, 5361-5368, 2004.

[18] Ki CS, Baek DH, Gang KD, Lee KH, Um IC, Park YH. "Characterization of gelatin nanofiber prepared from gelatin-formic acid solution". Polymer, 46(14), 5094-5102, 2005.

[19] Zhang YZ, Venugopal J, Huang ZM, Lim CT, Ramakrishna S. "Crosslinking of the electrospun gelatin nanofibers". Polymer, 47(8), 2911-2917, 2006.

[20] Meng ZX, Wang YS, Ma C, Zheng W, Li L, Zheng YF. "Electrospinning of PLGA/gelatin randomly-oriented and aligned nanofibers as potential scaffold in tissue engineering". Materials Science and Engineering: $C$, 30 (8), 1204-1210, 2010.

[21] Nguyen TH, Lee BT. "Fabrication and characterization of cross-linked gelatin electro-spun nano-fibers". Journal of Biomedical Science and Engineering, 3(12), 1117-1121, 2010.

[22] Aduba Jr DC, Hammer JA, Yuan Q, Yeudall WA, Bowlin GL, Yang H. "Semi-interpenetrating network (SIPN) gelatin nanofiber scaffolds for oral mucosal drug delivery". Acta biomaterialia, 9(5), 6576-6584, 2013.

[23] Ghasemi-Mobarakeh L, Prabhakaran MP, Morshed M, Nasr-Esfahani MH, Ramakrishna S. "Electrospun poly(epsilon-caprolactone)/gelatin nanofibrous scaffolds for nerve tissue engineering". Biomaterials, 29(34), 4532-4539, 2008.

[24] Kim MS, Jun I, Shin YM, Jang W, Kim SI, Shin H. "The development of genipin-crosslinked poly (caprolactone)(PCL)/gelatin nanofibers for tissue engineering applications". Macromolecular Bioscience, 10(1), 91-100, 2010.
[25] Li M, Guo Y, Wei Y, MacDiarmid AG, Lelkes PI. "Electrospinning polyaniline-contained gelatin nanofibers for tissue engineering applications". Biomaterials, 27(13), 2705-2715, 2006.

[26] Zhuang X, Cheng B, Kang W, Xu X. "Electrospun chitosan/gelatin nanofibers containing silver nanoparticles". Carbohydrate Polymers, 82(2), 524-527, 2010.

[27] Meng ZX, Xu XX, Zheng W, Zhou HM, Li L, Zheng YF, Lou X. "Preparation and characterization of electrospun PLGA/gelatin nanofibers as a potential drug delivery system". Colloids and Surfaces B: Biointerfaces, 84(1), 97-102, 2011.

[28] Meng ZX, Li HF, Sun ZZ, Zheng W, Zheng YF. "Fabrication of mineralized electrospun PLGA and PLGA/gelatin nanofibers and their potential in bone tissue engineering". Materials Science and Engineering: C, 33(2), 699-706, 2013.

[29] Yin-Guibo, Zhang-Youzhu, Bao-Weiwei, Wu-Jialin, De-bing S, Zhi-hui D, Wei-guo F. "Study on the properties of the electrospun silk fibroin/gelatin blend nanofibers for scaffolds". Journal of Applied Polymer Science, 111(3), 1471-1477, 2009.

[30] Bakkali F, Averbeck S, Averbeck D, Idaomar M. "Biological effects of essential oils-a review". Food and Chemical Toxicology, 46(2), 446-475, 2008.

[31] Hammer KA, Carson C, Riley T. "Antimicrobial activity of essential oils and other plant extracts". Journal of Applied Microbiology, 86, 985-990, 1999.

[32] Zhang H, Dudley EG, Davidson PM, Harte F. "Critical concentration of lecithin enhances the antimicrobial activity of eugenol against Escherichia coli". Applied and Environmental Microbiology, 83(8), e03467-16, 2017.

[33] Cavanagh H, Wilkinson J. "Biological activities of lavender essential oil", Phytotherapy research, 16, 301-308, 2002.

[34] Hui L, He L, Huan L, Xiaolan L, Aiguo Z. "Chemical composition of lavender essential oil and its antioxidant activity and inhibition against rhinitis-related bacteria", African Journal of Microbiology Research, 4(4), 309-313, 2010.

[35] Lis-Balchin M, Hart S. "Studies on the mode of action of the essential oil of LavenderLavandula angustifolia P. Miller.". Phytotherapy Research: An International Journal Devoted to Pharmacological and Toxicological Evaluation of Natural Product Derivatives, 13(6), 540-542, 1999.

[36] Kayaci F, Ertas Y, Uyar T. "Enhanced thermal stability of eugenol by cyclodextrin inclusion complex encapsulated in electrospun polymeric nanofibers". Journal of agricultural and food chemistry, 61(34), 8156-8165, 2013.

[37] Kim JH, Lee H, Jatoi AW, Im SS, Lee JS, Kim IS. "Juniperus chinensis extracts loaded PVA nanofiber: Enhanced antibacterial activity". Materials Letters, 181, 367-370, 2016.

[38] Mori CLSDO, Passos NAD, Oliveira JE, Altoé TF, Mori FA, Mattoso LHC, Tonoli GHD. "Nanostructured polylactic acid/candeia essential oil mats obtained by electrospinning". Journal of Nanomaterials, 16(1), 1-9, 2015.

[39] Chem 21 Guides and Metrics: Reagent Guides. "Pfizer and ACS GCI Pharmaceutical Roundtable selection guides". Green Solvents, http://learning.chem21.eu/methods-offacilitating-change/reagent-guides/pfizer/ (01.07.2019). 
[40] Cengiz F, Jirsak 0. "The effect of salt on the roller electrospinning of polyurethane nanofibers". Fibers Polymers, 10(2), 177-184, 2009.

[41] Song JH, Kim HE, Kim HW. "Production of electrospun gelatin nanofiber by water-based co-solvent approach". Journal of Materials Science: Materials in Medicine, 19(1), 95-102, 2008.

[42] Okutan N, Terzi P, Altay F. "Affecting parameters on electrospinning process and characterization of electrospun gelatin nanofibers". Food Hydrocolloids, 39, 19-26, 2014.
[43] Tan SH, Inai R, Kotaki M, Ramakrishna S. "Systematic parameter study for ultra-fine fiber fabrication via electrospinning process". Polymer, 46(16), 6128-6134, 2005.

[44] Ramakrishna S, Fujihara K, Teo W, Lim T, Ma Z. An Introduction to Electrospinning and Nanofibers. $1^{\text {st }}$ ed. Singapore, World Scientific, 2005. 